\title{
PENERAPAN MODEL PEMBELAJARAN COOPERATIVE SCRIPT \\ UNTUK MENINGKATKAN PRESTASI BELAJAR SISWA DALAM MATA PELAJARAN IPS DI KELAS III SDN 106162 MEDAN ESTATE
}

\author{
Martiana Panjaitan \\ Surel: martianapanjaitan@gmail.com
}

\begin{abstract}
ABSTRAK
Penelitian ini bertujuan untuk mengetahui penerapan strategi pembelajaran Model pembelajaran Cooperative Script dalam memahami Keanekaragaman suku bangsa dan budaya siswa kelas III semester genap SD Negeri 106162 Medan Estate dan pendekatan penelitian tindakan kelas PTK (Class Action Research) yang dilakukan 2 siklus. Siklus perencanaan, pelaksanaan, observasi dan refleksi. subyek penelitian tindakan kelas ini adalah siswa kelas III semester . Hasil penelitian tindakan kelas terlihat ada peningkatan hasil belajar yang dicapai siswa dalam menguasai materi.analisis data disimpulkan bahwa siklus 1belajar siswa nilai rata-rata hanya 65,75 data hasil observasi terhadap aktivitas siswa dari $60,42 \%$ pada siklus 1, meningkat pada siklus 2 menjadi 89,59\%.
\end{abstract}

Kata Kunci: IPS, Model Cooperative Scrip, Prestasi Belajar

\section{PENDAHULUAN}

Lajunya arus globalisasi sekarang ini, yang pengaruhnya semakin meluas ke seluruh penjuru dunia, memberikan respon bagi kita untuk lebih meningkatkan kualitas sumber daya manusia (SDM). Peningkatan kualitas sumber daya manusia tersebut harus dilakukan melalui jalur pendidikan, baik informal, formal, maupun nonformal.

Sistem Pendidikan Nasional ini, berorientasi pada pencapaian tujuan pendidikan nasional, serta mampu menjawab tantangan masa kini dan masa depan. Prioritas tersebut adalah pelaksanaan wajib belajar pendidikan dasar sembilan tahun yang bersamaan dengan peningkatan mutu, relevansi, efisiensi, efektifitas pada semua jenis, jenjang dan jalur pendidikan. Sekolah Dasar (SD) merupakan jenjang pendidikan yang paling bawah yang memberikan bekal dasar kepada siswa selaku generasi penerus bangsa.

Dalam proses belajar mengajar, penggunaan media, model dan metode pembelajaran sangat membantu suksesnya pembelajaran. Kenyataannya persolan ini belum mendapat perhatian oleh para guru. Dapat dikatakan bahwa apabila guru dalam memilih metode mengajar tepat dan dilaksanakan sesuai dengan

SD Negeri 106162 Medan Estate 
prosedur, diharapkan siswa. Dapat menerima dan memahami dengan baik apa yang diajarkan oleh guru. Permasalahan-permasalah itu sebagai berikut: tujuan pembelajaran belum tercapai karena guru kurang menguasai materi; Alat / media yang digunakan guru kurang sesuai atau kurang tepat dan siswa pasif karena guru dalam penyampaian materi kurang memakai metode yang tepat serta keaktifan anak kurang karena kegiatan hanya berpusat pada guru.

Identifikasi masalah dalam penelitian ini siswa tidak fokus pada pelajaran/kurangnya perhatian siswa terhadap materi pelajaran saat KBM, media/alat peraga yang kurang menarik, waktu yang singkat sementara guru harus dikejar target oleh kurikulum, dan semangat/minat belajar siswa rendah.

Dalam penelitian tindakan kelas ini diharapkan dapat bermanfaat sebagai berikut:

1. Bagi guru, dapat dipergunakan sebagai masukan bagi guru agar dalam menyampaikan materi pelajaran hendaknya selain memilih dan menggunakan metode pengajaran yang sesuai.

2. Bagi sekolah, sebagai referensi bagi sekolah dalam rangka untuk meningkatkan prestasi belajar IPS di SD Negeri 106162 Medan Estate Kabupaten Deli Serdang khususnya dan sekolah yang lain pada umumnya.
3. Bagi siswa, diharapkan dapat menimbulkan semangat belajar karena siswa dapat mengalami pembelajaran dengan berbagai macam variasi yang disampaikan oleh guru.

\section{METODE PENELTIAN}

Penelitian tindakan kelas ini dilaksanakan dalam waktu yang cukup singkat yaitu dalam waktu + Selama 3 bulan yaitu bulan Februari s/d April 2017. Subjek penelitian ini adalah seluruh siswa kelas III SD Negeri 106162 Kecamatan Medan Estate Kabupaten Deli Serdang Semester genap Tahun Pelajaran 2016/2017 sebanyak 36 siswa. Dalam penelitian ini menggunakan model yang didasarkan atas konsep pokok bahwa penelitian tindakan terdiri dari empat komponen pokok yang juga menunjukkan langkah pelaksanaan penelitian, yaitu: 1 . Perencanaan atau Planning 2. Tindakan atau Acting 3. Pengamatan atau Observasing dan Refleksi atau Reflekting (Arikunto, 2002: 83).

1. Tahap Perencanaan Tindakan Anak-anak yang akan ditingkatkan Prestasi belajar IPS dengan menggunakan Model pembelajaran Cooperative Script.

2. Tahapan Pelaksanaan Tindakan

a. Guru menerapkan metode Model pembelajaran Cooperative Script. 
b. Siswa belajar dalam situasi pembelajaran IPS dengan Model pembelajaran Cooperative Script.

c. Memantau perkembangan Prestasi belajar yang terjadi pada anak.

3. Tahapan Observasi

Tindakan

guru memonitor dan membantu siswa jika menemui kesulitan selama pengajaran IPS dengan Model pembelajaran

Cooperative Script.

4. Tahapan Refleksi Tahapan Rekomendasi

Mengadakan refleksi dan evaluasi dari kegiatan 1), 2), 3). Berdasarkan hasil refleksi dan evaluasi siklus I dibuat siklus II yang meliputi:

a) Tahap Perencanaan Tindakan

b) Tahap Pelaksanaan Tindakan

c) Tahap Observasi

d) Tahap Refleksi

Tahap ini dilakukan dengan merumuskan tindakan pembelajaran dengan media kongret yang tepat untuk meningkatkan Prestasi belajar IPS pada siswa kelas III SDN 106162 Kecamatan Medan Estate Kabupaten Deli Serdang.

Tahap pelaksanaan siklus II tidak jauh berbeda dengan siklus I. Pada siklus ke II di lakukan perbaikin terhadap kekurangan pada tahapan atau kegiatan siklus I.

Pada penelitian ini, pengumpulan data dilakukan dengan menggunakan teknik sebagai berikut: 1) Test awal untuk pengumpulan data awal berkenaan dengan kemampuan siswa terhadaf materi. 2) Post Test setelah siswa mengikuti suatu proses perlakuan yang dilakukan peneliti, guru memberikan soal-soal post test sehingga didapatkan hasil yang akurat dan dapat menggambarkan secara jelas kemampuan awal dan akhir siswa dalam menguasai materi tersebut. 3) Observasi, dengan menggunakan lembar observasi untuk mengumpulkan data tentang partisipasi dan aktivitas siswa dalam PBM dan implementasi Model pembelajaran Cooperative Script, 4) Diskusi antara guru, teman sejawat dan Observer, dengan menggunakan lembar pengamatan untuk refleksi hasil siklus PTK.

Alat pengumpulan data dalam penelitian ini adalah:

1) Tes, digunakan untuk mendapatkan data tentang pemahaman siswa berupa tes tertulis menggunakan butir soal/instrumen soal yang telah dirancang oleh peneliti sesuai dengan tujuan yang telah tertuang dalam kisi-kisi soal untuk mengukur pemahaman siswa sebagai hasil belajar siswa. 2) 
Observasi, untuk mengumpulkan data tentang partisipasi dan aktivitas siswa dalam PBM dan implementasi Model pembelajaran Cooperative Script, diskusi antara guru, teman sejawat dan Observer, untuk refleksi hasil siklus PTK.

Data yang diperoleh pada setiap kegiatan observasi dari setiap siklus dianalisis secara deskriftif dengan menggunakan teknik persentase untuk melihat kecenderungan yang terjadi dalam proses pembelajaran.

Analisis data dilakukan dalam suatu proses yang berarti bahwa pelaksanaannya sudah mulai dilakukan sejak pengumpulan data dan dikerjakan secara intensif sesudah meninggalkan lapangan. (Lexi J. Moleong, 1999: 104). Sedangkan teknik yang digunakan adalah teknik analisis data kualitatif yang dikembangkan oleh Miles dan Huberman (1992: 18-19) yang terdiri dari tiga tahap: (1) mereduksi data; (2) menyajikan data; (3) verifikasi dan menarik kesimpulan.

\section{HASIL DAN PEMBAHASAN}

Penelitian ini dimulai dengan pemberian tes awal yang berfungsi mengukur kemampuan dasar yang dimiliki siswa dan memastikan perlu tidaknya tindakan diberikan pada materi materi Keperluan sehari-hari. Berdasarkan hasil tes awal, diperoleh data sebanyak 33 orang siswa telah memenuhi syarat ketuntasan belajar dan 3 orang belum mencapai nilai ketuntasan belajar. Dari dua siklus tindakan yang diberikan, dapat dinyatakan bahwa ada peningkatan pemahaman siswa pada Materi Keperluan sehari-hari. Pada aktivitas siswa terjadi peningkatan, pada siklus 1 hanya $60,42 \%$, dan pada siklus 2 meningkat menjadi 89,59\%. Pada aktivitas guru juga meningkat, dari $69,45 \%$ pada siklus 1 , kemudian meningkat menjadi $90,28 \%$ pada siklus 2.

Peningkatan aktivitas di atas, menyebabkan pemahaman siswa juga meningkat. Pada Pemahaman siswa pada tes awal hanya 55,25\%. Setelah dilakukan tindakan meningkat menjadi $65,75 \%$ pada siklus 1, kemudian pada siklus 2 mencapai $91,35 \%$. Sesuai dengan indikator kinerja maka penelitian ini telah mencapai nilai aman dan penelitian tidak perlu dilanjutkan lagi. Perlu diketahui, sampai akhir siklus 2 masih ada nilai 3 orang siswa $(08,34 \%)$ belum mencapai ketuntaan minimal, sehingga diperlukan diberikan perlakuan khusus sehingga nilai siswa tersebut dapat tuntas. Dengan demikian, dari 36 orang siswa, 33 orang siswa $(91,67 \%)$ dinyatakan telah mencapai nilai ketuntasan minimal. 


\section{SIMPULAN}

Berdasarkan hasil analisis data dan pembahasan tentang materi Keperluan sehari-hari dengan Model pembelajaran Cooperative Script pada pelajaran IPS siswa kelas III SDN 106162 Medan Estate dapat disimpulkan sebagai berikut:

1. Pembelajaran Materi Keperluan sehari-hari dengan menggunakan Model pembelajaran Cooperative Script.

2. Pembelajaran materi Keperluan sehari-hari pelajaran IPS dengan menggunakan Model pembelajaran Cooperative Script meningkatkan aktivitas pembelajaran, mempertinggi interaksi antar siswa dan guru, serta meningkatkan pemahaman siswa terhadap materi Keperluan sehari-hari sehingga pemahaman siswa semakin tinggi.

3. Pembelajaran IPS dengan Model pembelajaran Cooperative Script memacu keberanian siswa sehingga dengan sendirinya rasa minder dan takut bagi siswa tertentu akan hilang, memotivasi siswa untuk lebih aktif dalam pembelajaraan, sehingga pembelajaran semakin hidup, dan memberikan kebebasan pada siswa untuk berkreasi dalam menyelesaikan tugasnya masingmasing.

\section{DAFTAR RUJUKAN}

A.M Sardiman (2005) Interaksi dan Motivasi Belajar Mengajar: Jakarta: Rajawali Press.

Agus suprijono. 2014. Cooperative Learning Teori dan Aplikasi PAIKEM. (Yogyakarta: Pustaka Belajar), h. 126.

Arikunto. 2002. Dasar-dasar Evaluasi Pembelajaran. Jakarta: Bumi Aksara.

Harjati. 2008. Psikologi Belajar. Jakarta: PT. Rineka Cipta.

Hidayati dkk. (2008). Pengembangan Pendidikan IPS SD. Jakarta: Direktorat

Slameto. 2003. Belajar Dan FaktorFaktor Yang Mempengaruhinya. Jakarta: Rineka Cipta.

Sumadi Suryabrata. 2003. Metode Penelitian. Jakarta: Rajawali.

Taneo, dkk. 2009. Kajian IPS SD 3 SKS. Jakarta: Ditjen PT Depdiknas.

Tukiran Taniredja, dkk. 2013. Model-model Pembelajaran Inovatif dan Efektif. Bandung: Alfabeta. 